\title{
Rise of the Composite Present Perfect Tense in Polish with the Verb mieć 'to Have' as an Auxiliary
}

\author{
IRENEUSZ KidA \\ Uniwersytet Ślaski w Katowicach, Ul. Bankowa 12, PL - 40-007 Katowice; \\ Akademia Techniczno-Humanistyczna w Bielsku-Białej, Ul. Willowa 2, \\ PL-43-309 Bielsko-Biała, irekkida@yahoo.com
}

\begin{abstract}
$\mathrm{V}$ prispevku je obravnavan nastanek perfekta, sestavljenega časa sodobne poljščine, in sicer v okviru treh indoevropskih jezikov angleščine, nemščine ter španščine. Čeprav kategorije perfekta jezikovni priročniki za poljski jezik ne navajajo, ga bo najbrž kmalu potrebno vključiti v slovnice in ga obravnavati ločeno, kot na primer v angleščini in španščini. Avtor prispevka prikazuje razvoj perfekta v angleščini in španščini ter prihaja do zaključka, da poljščina doživlja podoben proces.
\end{abstract}

In this paper we discuss the phenomenon of the rise of the complex present perfect tense in modern Polish in the context of three IndoEuropean languages: English, German, and Spanish. Although the category of the present perfect tense does not exist in grammar books of the Polish language, it will probably soon need to be included, and the present perfect tense will be treated as a separate grammatical tense, as is the case in English and Spanish. While discussing the trajectory of the development of the present perfect tense in English and Spanish, we arrive at the conclusion that the Polish language is undergoing a similar process.

Ključne besede: perfekt, gramatikalizacija, pripadnost, glagol imeti

Key words: present perfect tense, grammaticalisation, possession, verb 'to have'

\section{Introduction}

Owing to the process of grammaticalisation, nouns, adjectives, verbs, and other linguistic elements lose their expressivity (semantic force) and become more and more abstract. The loss of expressivity is nothing more than the loss of 
semantic force and the weakening of the original meaning of a given linguistic item. This loss is usually accompanied by phonetic reductions due to the process of phonetic attrition. It is hard to say which process precedes which, but it is quite logical to think that when a given linguistic item becomes weaker phonetically, that is, when it loses its phonetic load, it automatically becomes more abstract and conventional at the same time. Moreover, when it becomes more abstract and conventional, it loses its expressivity in the process of grammaticalisation, and either becomes part of the grammatical system, which tends to be abstract and conventional itself, or simply falls out of use altogether. Nevertheless, it is also common that some linguistic items lose their expressivity owing to frequency of use, whereby they do not necessarily undergo the process of phonetic attrition. In this paper we will concentrate on the process of grammaticalisation that leads to the rise of composite perfect tenses. We will take into consideration the grammaticalisation of the possessive verb have in English, German and Spanish, and see what are the implications of our discussion for the Polish language. The problem of the rise of the composite tense in Polish has attracted the attention of a number of linguists ${ }^{1}$ and continues to be interesting and attractive. In our paper we would like to present our own observations regarding this problem and suggest that it is perhaps about time that the Polish composite perfect tense should be included in Polish grammar books, as is the case with languages like English, German or Spanish.

\section{The present perfect tense in English}

Although the possessive verb have in English is undergoing a slow process of grammaticalisation, it is still semantically strong enough to be capable of expressing possession. For example, if somebody says in English I have a car, the sentence means that this person is in the possession of an object called a car. This possessive quality of the verb have has been used in English for talking about actions that have recently been completed and whose result can still be seen in the present ${ }^{2}$. In order to express such actions linguistically, it is enough to combine the verb to have in the appropriate person with the past participle, as in the example below:

singular 'I have bought a car' plural

1. I have bought a car

2. you have bought a car

3. he has bought a car
1. we have bought a car

2. you have bought a car

3. they have bought a car

\footnotetext{
${ }^{1}$ See, for example, Nitsch (1913), Pisarkowa (1963), Weiss (1977), Maslov (1988), Nedjalkov and Jaxontov (1988), Koronczewski (1993) and Weimer (2005).

${ }^{2}$ See, for example, Thomson and Martinet (1986) and Graver (1986).
} 
In this usage of the verb to have, there is still a shade of possession, and the sentence I have bought a car is not so semantically distant from the sentence I have a car, which in fact could take the form I have got a car, in which the verb to have can be interpreted as a possessive verb, on the one hand, or as an auxiliary verb, on the other. Below we illustrate the two conjugation paradigms in the present tense: I have a car and I have got a car:

singular 'I have a car $=$ I have got a car' plural

I have a car $=$ I have got a car you have a car $=$ you have got a car

he/she has a car $=$ he/she has got a car we have a car = we have got a car you have a car $=$ you have got a car they have a car = they have got a car

Whereas the sentence I have a car expresses the fact that somebody is in the possession of a car, the sentence I have got a car expresses a recently completed action whose result can be seen now in the present. By analogy, whereas the sentence $I$ have a car expresses the fact that somebody is in possession of a car, the sentence I have bought a car expresses a recently completed action whose result can be seen now in the present. The periphrasis to have + past participle now has the status of a separate grammatical tense in English which is called 'the present perfect tense'. However, it is difficult to say when exactly this periphrasis acquired the status of a distinct tense in English because both the verb to have that expresses possession and the verb to have that functions as an auxiliary verb in a present perfect sentence have the same form; there is no formal difference between the two verbs. If the two verbs having the same form had become phonetically different at some point in their respective histories, it would be much easier to say when the verb to have began to acquire the function of an auxiliary verb, and thus when it gave rise to a new grammatical tense in English. One thing can be definitely established: that in the periphrasis to have + past participle, the verb to have was fully expressive at first and its semantic force was very strong and comparable to the situation when it functioned as a possessive verb. After a time, being an integral part of the periphrasis to have + past participle, the verb to have began to weaken semantically, and its possessive meaning became progressively weaker. At present the force of the verb to have, as an integral part of the periphrasis in question, cannot in fact be compared to the possessive force of the verb to have expressing possession. It would therefore be conjectural and speculative to say when the verb to have, together with the accompanying past participle, started to form a new grammatical tense in English. ${ }^{3}$

${ }^{3}$ For more information on the rise of the English grammatical system, see Danison (1993). 


\section{The present perfect tense in Spanish}

In Spanish, the situation with the present perfect tense is quite analogical to that of the present perfect tense in English, which we discussed above; the present perfect tense in Spanish is in fact called the 'preterite perfect', but this does not change the fact that it can express, among other things, the same kind of actions as the English present perfect. ${ }^{4}$ The Spanish present perfect tense is also formed by combining the verb haber 'to have', 'to be' in the appropriate person with the past participle. The example below illustrates how it is formed:

singular 'I have bought a car' plural

1. yo he comprado un coche

'I have bought a car'

2. tú has comprado un coche

'you have bought a car'

3. él/ella ha comprado un coche

'he/she has bought a car'
1. nosotros hemos comprado un coche 'we have bought a car'

2. vosotros habéis comprado un coche 'you have bought a car'

3. ellos/ellas han comprado un coche 'they have bought a car'

However, at some point in the history of the Spanish language, the possessive verb haber 'to have' began to lose its expressivity (semantic force) and soon was semantically too weak to fulfill its original function. First of all, in the process of phonetic attrition, its form was reduced almost completely; it thus became too abstract for language users to express possession. In contrast, although the form of the verb havoir 'have' has also been much reduced in French, it is still capable of expressing possession in this language. In this situation, language users needed a more expressive, 'down-to-earth' word for expressing possession in Spanish. It so happened that the verb tener 'to keep', 'to have', 'to hold' was selected, probably not consciously, as the best candidate to substitute the already phonetically and semantically weak haber 'to have', which from then on became increasingly used as an auxiliary verb in the present perfect tense. Below we present the conjugation paradigm of the verb tener 'to have' in a typical possessive context:

singular 'I have a car' plural

1. yo tengo coche

'I have a car'

2. tú tienes coche

'you have a car'

3. él/ella tiene coche

'he/she has a car'
1. nosotros tenemos coche 'we have a car'

2. vosotros tenéis coche 'you have a car'

3. ellos/ellas tienen coche 'they have a car'

${ }^{4}$ See, for example, Seco (1973) and Castro (1998). 
The same paradigm for the verb haber 'to have', 'to be' is completely unacceptable in the context of expressing possession, and nothing like the conjugation paradigm presented below exists in Modern Spanish:

singular 'I have a car' plural

1. yo he coche

'I have a car'

2. tú has coche

'you have a car'

3. él/ella ha coche

'he/she has a car'
1. nosotros hemos coche

'we have a car'

2. vosotros habéis coche 'you have a car'

3. ellos/ellas han coche 'they have a car'

Whereas a long time ago the verb haber 'to have' could be used in this way in possessive contexts, it can no longer fulfill this function because at some point in the history of the Spanish language it became semantically too weak to express possession. Therefore, in Spanish, unlike in English, it is theoretically easier to establish the approximate point when we can talk about the appearance of a new complex grammatical tense - the present perfect - because the moment that the verb tener 'to keep', 'to have', 'to hold' began to be used in regular possessive contexts, we can surely say that the verb haber 'to have', 'to be' was already becoming part of the abstract grammatical system. In order to establish when this differentiation took place, it would be necessary to do perform analysis on the basis of existing corpora of Mediaeval Spanish. ${ }^{5}$

\section{The present perfect tense in German}

German also has a distinct category of the present perfect tense, which is called 'Perfekt'. This grammatical tense, unlike in English or in Spanish, can be used interchangeably with the preterite tense and is in fact the preferred tense for talking about past events. Nevertheless, some of its uses coincide with the uses of the English and Spanish present perfect tenses: for example, talking about recent actions whose result can be seen in the present. Therefore, we could call it a 'preterite/present perfect'. The German perfect tense in question is formed by combining the verb haben 'to have' in the appropriate person with the past participle. Below we present the conjugation paradigm in the present based on the action concerning buying a car:

${ }^{5}$ For example, on the basis of the on-line electronic corpus of Spanish produced by Davis

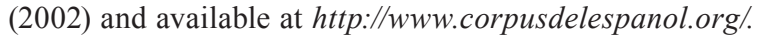


plural

1. ich habe ein Auto gekauft

'I have bought a car'

2. du hast ein Auto gekauft

'you have bought a car'

3. er/sie hat ein Auto gekauft

'he/she has bought a car'
1. wir haben ein Auto gekauft

'we have bought a car'

2. ihr habt ein Auto gekauft

'you have bought a car'

3. sie haben ein Auto gekauft

'they have bought a car'

As can be noticed, unlike in Spanish and English, the past participle gekauft 'bought' can be separated from the auxiliary verb haben 'to have'. This is because German is a V2 language, which means that the finite verb (or in this case an auxiliary verb which is also a finite verb) has to occupy the second position, whereas the past participle, not being a finite verb, usually wanders to the end position in the sentence, not necessarily immediately next to its auxiliary verb. This never happens in Spanish or English. The German verb that is used to express possession is also haben 'to have', 'to possess'. If we were to give the present conjugation paradigm of the verb haben expressing possession, we would obtain something like this:

singular

1. ich habe ein Auto

'I have a car'

2. du hast ein Auto

'you have a car'

3. er/sie hat ein Auto

'he/she has a car'
'I have a car'

plural

As can be observed, the verb haben 'to have', 'to possess' behaves exactly like the English verb to have in this sense.

\section{The present perfect tense in Polish?}

In Polish grammatical terminology, we lack anything like the present perfect tense formed on the basis of the verb miec 'to have' in the appropriate person plus the accompanying past participle. In other words, the present perfect tense does not exist in Polish grammar books ${ }^{6}$ and we cannot be sure if it ever will. However, it is only in the nomenclature of Polish grammar that this tense is non-existent; in practice, language users often employ the periphrasis mieć 'to

\footnotetext{
${ }^{6}$ See, for example, Bartnicka and Satkiewicz (1980) and Nagórko (1997).
} 
have' + past participle in everyday situations, and this is why it is perhaps about time that the periphrasis should be included in Polish grammar books. Let us have a look at the conjugation paradigm of the periphrasis in the present tense:

singular 'I have written two chapters of the thesis' plural

1. ja mam napisane dwa rozdziały pracy

'I have written two chapters of the thesis'

2. ty masz napisane dwa rozdziały pracy 'you have written two chapters of the thesis',

3. on/ona ma napisane dwa rozdziały pracy

'he/she has written two chapters of the thesis',
1. my mamy napisane dwa rozdziały pracy

'we have written two chapters of the thesis'

2. wy macie napisane dwa rozdziały pracy 'you have written two chapters of the thesis'

3. oni/one mają napisane dwa rozdziały pracy 'they have written two chapters of the thesis'

We have changed the example 'I have bought a car' into the example 'I have written two chapters of the thesis' because the example with 'buying the car' would not work well here. This is because the mieć 'to have' + past participle periphrasis, it seems, is still reserved for particular contexts. Thus, the sentence ja mam kupiony samochód 'I have bought a car' would sound odd because the sentence would be sort of a description of what kind of car one has, rather than an expression of the fact that one has recently bought a car. It could, for example, be compared to having a blue car, as in the following example:

singular 'I have a blue car' plural

\begin{tabular}{ll}
\hline $\begin{array}{l}\text { 1. ja mam niebieski samochód } \\
\text { 'I have a blue car' }\end{array}$ & $\begin{array}{l}\text { 4. my mamy niebieski samochód } \\
\text { 'we have a blue car' }\end{array}$ \\
$\begin{array}{ll}\text { 2. ty masz niebieski samochód } \\
\text { 'you have a blue car' }\end{array}$ & $\begin{array}{l}\text { 5. wy macie niebieski samochód } \\
\text { 'you have a blue car' }\end{array}$ \\
$\begin{array}{l}\text { 3. on/ona ma niebieski samochód } \\
\text { he/she has a blue car' }\end{array}$ & $\begin{array}{l}\text { 6. oni/one mają niebieski samochód } \\
\text { 'they have a blue car' }\end{array}$
\end{tabular}

The contexts to which the periphrasis in question is reserved in Polish are usually those that involve perfective transitive verbs in resultative constructions with the adverbial $j u \dot{z}$ 'already/yet'; as regards imperfective verbs, the periphrasis never works well. Apart from the verb napisać 'to read', we can also include in this list verbs like przejechać 'to do/to cover (+perf.)' (of a number of kilometers), zdobyc' 'to climb (+perf.)' (of a peak), wykopać 'to dig (+perf.)', etc. These are examples for the three perfective transitive verbs: 1. Mam już przejechane 1000 kilometrów 'I have already done 1000 kilometres', etc. with other persons, 2. Mam już zdobyte te dwa najwyższe szczyty 'I have already climbed these two highest peaks', etc. with other persons, 3. Mam już wykopane trzy doty 'I have dug three holes already', etc. with other persons. However, some of the utterances can sound ambiguous, especially when there is a strong 
possibility to interpret the subject as not being the agent of the action. This happens because, unlike in English, German or Spanish, in Polish utterances with the periphrasis in question, the subject of an action is not necessarily the agent of the same action ${ }^{7}$. Thus, although in all these examples the tendency of a Polish native speaker would be to identify the subject with the agent, it is not in fact clearly known whether the subject is the agent or not, and some further context is necessary for clarity. Moreover, there are cases in which the Polish periphrasis in question is used, but the subject is never the agent, even though we are dealing with a perfective verb. For example, Mam nakazane, aby tam nie chodzić 'I am not allowed to go there (i.e. somebody told me not to go there)', etc. with other persons. In this type of utterance, verbs of forbidding are employed and always mean that somebody else ordered us not to do something. In English, German or Spanish the analogical structures would always mean that it is the subject who does the ordering.

It is probably only a matter of time before the periphrasis miec 'to have' + past participle will be extended to all contexts (English and Spanish probably went through such a transition phase), and the paradigm presented below will be completely acceptable:

$$
\text { singular 'I have a bought car' plural }
$$

\begin{tabular}{ll}
\hline $\begin{array}{l}\text { 1. ja mam kupiony samochód } \\
\text { 'I have a bought car' }\end{array}$ & $\begin{array}{l}\text { 4. my mamy kupiony samochód } \\
\text { 'we have a bought car' }\end{array}$ \\
$\begin{array}{ll}\text { 2. ty masz kupiony samochód } \\
\text { 'you have a bought car' }\end{array}$ & $\begin{array}{l}\text { 5. wy macie kupiony samochód } \\
\text { 'you have a bought car' }\end{array}$ \\
$\begin{array}{l}\text { 3. on/ona ma kupiony samochód } \\
\text { 'he/she has a bought car' }\end{array}$ & $\begin{array}{l}\text { 6. oni/one mają kupiony samochód } \\
\text { 'they have a bought car' }\end{array}$
\end{tabular}

In the above example, the English translation conveys the idea of how it still feels when one uses the Polish periphrasis mieć 'to have' + past participle in contexts which still do not qualify for the present perfect tense. For the time being, the translation 'I have a bought car' sounds more natural than the translation 'I have bought a car' which would be used if we had to do with a mature present perfect construction or at least with a mature periphrasis miec 'to have' + past participle used with a perfective sense. Since the periphrasis in question does not yet function as a separate tense in Polish, it can still only have the status of a periphrasis or no status at all. It is, however, interesting to note that this periphrasis, as in English and Spanish, is used to express recently completed actions whose result can be seen in the present; we can observe such

${ }^{7}$ Actually, in English we can obtain a situation in which we use the verb have as in the Present Perfect tense but where the subject is different from the agent. For example, in the utterance I have had my car washed, the subject 'I' is not the agent, and in the utterance it is stated that somebody else has washed the car for me. 
behaviour in the above example about having written two chapters of the thesis. So, the process starts in a similar way as the English, German and Spanish periphrases did. It is quite probable that one day it will be considered a separate grammatical tense in Polish. This probability increases greatly because more and more people use English, German, and to a lesser extent Spanish, in their everyday life, which fact may lead to language transfer, whereby present perfect structures will be transferred to Polish and give rise to a new grammatical tense. Moreover, as was the case with the English and German, it will probably be quite difficult to say when exactly we should consider the periphrasis mieć 'to have' + past participle as a distinct tense because of the lack of a formal difference between the possessive mieć 'to have' and the auxiliary miec 'to have'. In the example below we present a conjugation paradigm for mieć 'to have' as a possessive verb:

singular 'I have a car' plural

1. ja mam samochód

'I have a car'

2. ty masz samochód 'you have a car'

3. on/ona ma samochód he/she has a car'
4. my mamy samochód

'we have a car'

5. wy macie samochód 'you have a car'

6. oni/one mają samochód 'they have a car'

If one day the possessive verb mieć 'to have' begins to lose its semantic force for expressing possession or loses it completely, the best candidate for expressing possession in Polish will most likely be the verb posiadać 'to possess'. As a matter of fact, this verb is nowadays used interchangeably with the verb mieć for expressing possession. Although it is more likely to appear in formal contexts, it can also be used in informal situations. The verb mieć 'to have' can be used in both formal and informal situations. Below we present the conjugation paradigm of the verb posiadac 'to possess':

singular

1. ja posiadam samochód

'I possess a car'

2. ty posiadasz samochód

'you possess a car'

3. on/ona posiada samochód he/she possesses a car'
'I possess a car'

plural

4. my posiadamy samochód

'we possess a car'

5. wy posiadacie samochód 'you possess a car'

6. oni/one posiadają samochód 'they possess a car'

A less likely candidate for expressing possession in Polish (after the verb miec 'to have' has completed its process of grammaticalisation and become an 
auxiliary verb and thus part of the grammatical system of tenses) will probably be the verb trzymac' 'to hold, to keep' by analogy to the Spanish verb tener 'to keep', 'to have', 'to hold'. However, for the time being it is very difficult for a Polish person to imagine this verb as a verb expressing possession, whereas the verb posiadac 'to possess' is perfectly acceptable. Below we present an unacceptable conjugation paradigm of the verb trzymac 'to hold, to keep' functioning as a possessive verb:

singular 'I hold/keep a car' plural

1. ja trzymam samochód

'I hold/keep a car'

2. ty trzymasz samochód 'you hold/keep a car'

3. on/ona trzyma samochód he/she holds/keeps a car'
4. my trzymamy samochód

'we hold/keep a car'

5. wy trzymacie samochód 'you hold/keep a car'

6. oni/one trzymają samochód 'they hold/keep a car'

The verb trzymać 'to hold, to keep' is indeed used in possessive contexts but is restricted to specific areas only. For example, it is used to talk about animals and power. Let us first take a conjugation paradigm related to talking about keeping animals:

$$
\text { singular 'I keep horses, cows, sheep and pigs' plural }
$$

1. ja trzymam konie, krowy, owce i świnie

'I keep horses, cows, sheep and pigs'

2. ty trzymasz konie, krowy, owce i świnie 'you keep horses, cows, sheep and pigs'

3. on/ona trzyma konie, krowy, owce i świnie 'he/she keeps horses, cows, sheep and pigs'
4. my trzymamy konie, krowy, owce i świnie 'we keep horses, cows, sheep and pigs'

5. wy trzymacie konie, krowy, owce i świnie 'you keep horses, cows, sheep and pigs'

6. oni/one trzymają konie, krowy, owce i świnie 'they keep horses, cows, sheep and pigs'

And below we present a conjugation paradigm related to holding power:

singular 'I hold power in this country' plural

1. ja trzymam władzę w tym kraju 'I hold power in this country'

2. ty trzymasz władzę w tym kraju 'you hold power in this country'

3. on/ona trzyma władzę w tym kraju 'he/she holds power in this country'
4. my trzymamy władzę w tym kraju 'we hold power in this country'

5. wy trzymacie władzę w tym kraju 'you hold power in this country'

6. oni/one trzymają władzę w tym kraju 'they hold power in this country' 
We could seek other candidates for expressing the kind of possession that the verb mieć 'to have' expresses now, but this would probably be too speculative and farfetched. However, we can be confident of one thing: that the candidate will be chosen naturally, unconsciously and without premeditation because the grammar of a language comes into being in this way first and the description of a grammar comes next; although this is the natural sequence of events, language histories do contain cases where certain grammatical rules have been prescribed and imposed on the language, and therefore on language users; this is what is referred to as prescriptivism and can play a major role in the creation of the grammar of a given language.

To cap it all, if the periphrasis mieć 'to have' + past participle continues to be used in everyday situations, and it most likely will (at least in some contexts at first, and then probably in further contexts), sooner or later somebody will come to the conclusion that in fact we are dealing with a separate grammatical tense in Polish and therefore there will be a need to give it a name describing a new grammatical tense in Polish, as was the case with English, German and Spanish. We think that it is just a matter of time and frequency of use.

\section{Conclusions}

Over time, words lose their expressive force and either lexicalise, fall out of use, or simply became part of the grammatical system of a language. The last process is called grammaticalisation and in this process some words are subconsciously chosen as the best candidates to become part of the grammar. The process of grammaticalisation is, among other things, responsible for the emergence of new grammatical tenses, which often means that the 'older' tenses necessarily disappear. If we take a closer look at Polish, we observe how a new tense - the present perfect - is being created; we can easily see that analogical situations have taken place in English, German and Spanish. For the time being, we cannot yet speak of a distinct tense in Polish, but it is more than probable that the periphrasis miec 'to have' + past participle, if we can call it a periphrasis, will gain more and more ground for being considered as a separate tense in Polish, especially if the verb mieć 'to have' loses something of its original meaning and thus its expressivity. For the moment it is fully expressive and is treated as a verb expressing possession, even in the periphrasis mieć 'to have' + past participle. However, in certain contexts the periphrasis in question starts to resemble a true present perfect tense. It would be ideal if the verb mieć 'to have' were reduced phonetically and semantically to such an extent that it would be impossible to use it for expressing possession. In such a case, possession would need to be expressed by some other verb denoting possession, for example the verb posiadac 'to possess' or the verb trzymać 'to hold, to keep', while the verb mieć 'to have' would acquire a purely auxiliary function in the new present perfect tense, as is the case 
in Spanish $^{8}$. In such a situation it would be possible to establish the point at which the present perfect tense was born in Polish.

\section{REFERENCES}

Barbara BARTNICKA and Halina SATKIEWICZ, 1980: Gramatyka języka polskiego: podręcznik dla cudzoziemców. Warszawa: Wiedza Powszechna.

Francisca CASTRO, 1998: Uso de la gramática española. Edelsa.

David DENISON, 1993: English Historical Syntax: Verbal Constructions. London and New York: Longman.

Mark DAVIS, 2002: Corpus del Español. Available at: http://www.corpusdelespanol. org/.

Brian DEREK GRAVER, 1986: Advanced English Practice. Oxford: Oxford University Press.

Andrzej KORONCZEWSKI, 1993: Die Kategorie des Perfekts im Polnischen. Studies in Polish Morphology and Syntax. Eds. G. Hentschel, R. Laskowski. Munich. 251-257.

Jurij MASLOV, 1988. Resultative, Perfect, and Aspect. Typology of Resultative Constructions. Ed. V. P. Nedjalkov. Amsterdam-Philadelphia. 63-85.

Alicja NAGÓRKO, 1997: Zarys gramatyki polskiej. Warszawa: PWN.

Vladimir NEDJALKOV, Sergej JAXONTOV, 1988. The typology of resultative constructions. Typology of Resultative Constructions. Ed. V. P. Nedjalkov. AmsterdamPhiladelphia. 3-62.

Kazimierz NITSCH, 1913: Nowy czas przeszły złożony. Język Polski 1. 102-106.

Krystyna PISARKOWA, 1963: Składniowa funkcja imiesłowów z czasownikiem mieć. Język Polski XLIV. Kraków. 231-237.

Rafael SECO, 1973: Manual de gramática española. La Habana.

Audrey Jean THOMSON and Agnes V. MARTINET, 1986: A Practical English Grammar. Oxford: Oxford University Press.

\footnotetext{
${ }^{8}$ In Spanish, the grammaticalised verb haber is not only used in the complex perfective tenses but it also gave rise to the inflectional endings of the Spanish future simple tense, which at first was a complex tense, as in yo comprar he un coche 'I have to buy a car' > yo compraré un coche 'I will buy a car'. The verb haber is also used as an existential verb, as in aqui hay un coche 'there is a car here'. As a matter of fact, the verb mieć 'to have' is also used as an existential verb in Polish but, unlike in Spanish, its range of operation in this sense is restricted only to negative sentences, as in tutaj nie ma samochodu 'there is no car here'. In affirmative and interrogative sentences, Polish employs, respectively, the verb być 'to be', as in tutaj jest samochód 'there is a car here' and czy tutaj jest samochód? 'is there a car here?'
} 
- Rise of the Composite Present Perfect Tense in Polish with the Verb mieć 'to Have' ... -

Daniel WEISS, 1977: Syntax und Semantik polnischer Partizipialkonstruktionen im Rahmen einer generativ-transformationellen Sprachbeschreibung. Bern.

Björn WIEMER and Markus GIGER, 2005: Resultativa in den nordslavischen und baltischen Sprachen (Bestandsaufnahme unter arealen und grammatikalisierungstheoretischen Gesichtspunkten). Munich, Newcastle.

\section{NASTANEK SESTAVLJENEGA ČASA PERFEKT V POLJŠČINI Z GLAGOLOM MIEĆ 'IMETI' KOT POMOŽNIM GLAGOLOM}

Avtor članka obravnava začetke novega slovničnega časa v poljščini - perfekta. Trenutno ima perfekt $\mathrm{v}$ poljščini vlogo neformalnega časa, ki se uporablja v vsakdanji komunikaciji in je omejen le na nekatere kontekste, v katerih spominja na present perfekt, zaradi česar ga lahko z njim identificiramo. Ta neformalni čas se trenutno v poljščini ne obravnava kot poseben čas, zaradi česar še ni vključen v poljske slovnice, vendar pa bo, če se bo še naprej uporabljal in se celo razširjal na druge kontekste, nedvomno pritegnil pozornost jezikoslovcev, ki se ukvarjajo s poljsko slovnico. Posledično bo formaliziran in obravnavan kot poseben čas, tako kot v angleščini, nemščini, španščini in številnih drugih indoevropskih jezikih.

Avtor prispevka sprva obravnava perfekt $v$ angleščini in španščini, kjer se ta čas imenuje "preterite perfect«. Nato se posveti tako imenovanemu »Perfectu« v nemščini. Razprava o razvoju perfekta $\mathrm{v}$ treh indoevropskih jezikih postane osnova za razpravljanje o stanju perfekta $\mathrm{v}$ poljskem jeziku. Zdi se, da znotraj indoevropskih jezikov obstaja tendenca za ustvarjanje ločene časovne kategorije na podlagi glagola imeti, ki se veže s preteklim deležnikom. Ta težnja je opazna tudi v poljščini in če se bo nadaljevala, se bo potrebno perfekta lotiti s formalnega vidika, kar bo vodilo $\mathrm{k}$ oblikovanju novega časa $\mathrm{v}$ poljskem časovnem sistemu. 